\title{
Erratum: Rodrigo-Mor et al. Principles of Charge Estimation Methods Using High-Frequency Current Transformer Sensors in Partial Discharge Measurements. Sensors 2020, 20, 2520
}

\author{
Armando Rodrigo-Mor *, Fabio A. Muñoz and Luis Carlos Castro-Heredia \\ Electrical Sustainable Energy Department, Delft University of Technology, 2628 CD Delft, The Netherlands; \\ f.a.munozmunoz-1@tudelft.nl (F.A.M.); L.C.CastroHeredia@tudelft.nl (L.C.C.-H.) \\ * Correspondence: A.RodrigoMor@tudelft.nl
}

check for updates

Citation: Rodrigo-Mor, A.; Muñoz, F.A.; Castro-Heredia, L.C. Erratum: Rodrigo-Mor et al. Principles of Charge Estimation Methods Using High-Frequency Current Transformer Sensors in Partial Discharge Measurements. Sensors 2020, 20, 2520. Sensors 2021, 21, 6010. https:// doi.org/10.3390/s21186010

Received: 26 July 2021

Accepted: 16 August 2021

Published: 8 September 2021

Publisher's Note: MDPI stays neutral with regard to jurisdictional claims in published maps and institutional affiliations.

Copyright: (C) 2021 by the authors. Licensee MDPI, Basel, Switzerland. This article is an open access article distributed under the terms and conditions of the Creative Commons Attribution (CC BY) license (https:/ / creativecommons.org/licenses/by/ $4.0 /)$.
The authors wish to make the following erratum to this paper [1]: the summation symbol in the Equations (11) and (12) should be a product symbol.

The corrected Equations (11) and (12) appear below:

$$
\begin{gathered}
H(s)=\frac{U(s)}{I(s)}=\frac{\alpha \cdot s \cdot \prod_{i=1}^{i=m}\left(s+z_{i}\right)}{\prod_{j=1}^{j=n}\left(s+p_{j}\right)} \\
\frac{U(s)}{s^{2}}=I(s) \frac{\alpha \cdot \prod_{i=1}^{i=m}\left(s+z_{i}\right)}{s \cdot \prod_{j=1}^{j=n}\left(s+p_{j}\right)}
\end{gathered}
$$

The authors apologize for any inconvenience caused and state that the scientific conclusions are unaffected. The original article has been updated.

Conflicts of Interest: The author declares no conflict of interest.

\section{Reference}

1. Rodrigo-Mor, A.; Muñoz, F.A.; Castro-Heredia, L.C. Principles of Charge Estimation Methods Using High-Frequency Current Transformer Sensors in Partial Discharge Measurements. Sensors 2020, 20, 2520. [CrossRef] [PubMed] 